\title{
Underground dinosaur tracksite inside a karst of southern France: Early Jurassic tridactyl traces from the Dolomitic Formation of the Malaval Cave (Lozère)
}

\author{
Jean-David Moreau ${ }^{1,2^{*}}$, Vincent Trincal ${ }^{3}$, Daniel André ${ }^{4}$, Louis Baret ${ }^{5}$, Alain Jacquet ${ }^{5}$, \\ and Michel Wienin ${ }^{6}$ \\ ${ }^{1}$ CNRS UMR 6282 Biogéosciences, Université de Bourgogne Franche-Comté, 6, boulevard Gabriel, 21000 Dijon, France \\ ${ }^{2}$ Centre d'étude et de conservation Jean Mazel-Musée du Gévaudan, allée Raymond Fages, 48000 Mende, France \\ ${ }^{3}$ IMT Lille Douai, Université de Lille, Département GCE, Ecole des Mines, 764, boulevard Lahure, 59508 Douai, France \\ ${ }^{4}$ Association Malaval, La Lèche, 48320 Ispagnac, France \\ ${ }^{5}$ Association Paléontologique des Hauts Plateaux du Languedoc, 14, chemin des Ecureuils, 48000 Mende, France \\ ${ }^{6}$ Parc National des Cévennes, Place du Palais, 48400 Florac, France
}

\begin{abstract}
Although underground dinosaur tracksites inside anthropic cavities such as mines or tunnels are well-known throughout the world, footprints inside natural karstic caves remain extremely rare. The Malaval Cave (Lozère, southern France) is well-known by speleologists for the abundance and the exceptional quality of acicular and helictite aragonite speleothems. Recent palaeontological prospecting inside this cave allowed the discovery of tridactyl dinosaur tracks. Here, a detailed study of theropod footprints was for the first time conducted inside a natural karstic cave, using photogrammetric imaging technique. Tracks from the Malaval Cave are located inside the "Super-Blanches" galleries. More than 26 footprints were identified. They are Hettangian in age (Lower Jurassic) and preserved as both in situ convex hyporeliefs and ex situ concave epireliefs. Tree morphotypes are distinguished, (i) "DilophosauripusKayentapus" morphotype, (ii) "Eubrontes" morphotype, and (iii) "Grallatorid" morphotype. Sedimentological and mineralogical analyses of the tracksite indicate that the depositional environment varied from periodically emergent subtidal to intertidal/supratidal flat marsh. This work highlights the great interest and importance of palaeoichnological prospecting in karst caves. This is particularly true for the Causses Basin where hundreds of natural cavities were reported by speleologists in the formations yielding dinosaur traces.
\end{abstract}

Keywords: dinosaur tracks, Lower Jurassic, karst caves, photogrammetry, Causses Basin

Received 24 August 2017; Revised 22 November 2017; Accepted 25 November 2017

Citation: $\quad$ Moreau J.-D., Trincal V., André D., Baret L., Jacquet A. and Wienin M., 2018. Underground dinosaur tracksite inside a karst of southern France: Early Jurassic tridactyl traces from the Dolomitic Formation of the Malaval Cave (Lozère). International Journal of Speleology, 47 (1), 29-42. Tampa, FL (USA) ISSN 0392-6672 https://doi.org/10.5038/1827-806X.47.1.2149

\section{INTRODUCTION}

Underground dinosaur tracksites inside anthropic cavities (e.g., clay underground quarries or coal mines, tunnels of railways) are well-known in several countries such as Australia (e.g., Cook et al., 2010) and United-States (e.g., Peterson, 1924; Parker \& Balsley, 1989; Parker \& Rowley, 1989; Lockley \& Hunt, 1995). In Europe, such palaeoichnological sites are less common, but reported in few localities from France (e.g., the Fondamente Cave; Sciau, 2003), Italy (Belvedere et al., 2008; Petti et al., 2011), and Sweden (Ahlberg \& Siverson, 1991; Gierliński, \& Ahlberg, 1994). In contrast, although some outdoor tracksites were reported near the entrance of karstic caves (e.g., the Sataplia Cave, Georgia; Kralik et al., 2014), the occurrences of underground dinosaur tracksites inside natural karstic caves remain extremely rare over the world and in Europe (e.g., Bramabiau Cave in southern France; Ellenberger, 1988).

Because of the abundance and the diversity of footprints, in France, the most important Early Jurassic megatracksite is the Causses Basin (southern France; e.g., Monod, 1935; Thaler, 1962; Ellenberger, 1988; Demathieu, 1990, 1993; Demathieu \& Sciau, 1999; Demathieu et al., 2002; Moreau et al., 2012a, $2012 \mathrm{~b}, 2014$ and references therein). In this basin, dozens of outdoor tracksites were discovered during the last decades. Otherwise, hundreds of karst caves were reported by speleologists in geological formations yielding footprints (Hettangian-Sinemurian and Bathonian). However, due to the relative difficulty 
of access to the far galleries of cavities, the palaeontologists rarely had the opportunity to study potential rock surfaces bearing tracks.

In this paper, we report an underground tracksite in the northern part of the Causses Basin (Fig. 1). It was discovered during palaeontological and speleological prospecting inside the Malaval Cave. The Malaval Cave is well-known by speleologists for the abundance and the exceptional quality of acicular and helictite aragonite speleothems (e.g., Gajac \& Rouire, 1949; Gajac, 1963; André, 1992, 2014). Some of them are even blue due to copper coloration (Fig. 2). In some parts of the karstic network, the whiteness of speleothems is such that a group of galleries was called the "Super-Blanches" (means "super white"). The lowermost Jurassic dinosaur tracks described in this study were recently discovered in these galleries. For the first time, we used photogrammetry to study such an unusual palaeontological site inside a karstic cavity in Europe. Here, we characterize this new tracksite and compare footprints with coeval material to determine the possible trackmakers. Then palaeoenvironments are discussed using palaeontology, sedimentology, and mineralogy.

\section{GEOGRAPHICAL AND GEOLOGICAL SETTING}

The Malaval Cave is located in the Lozère department, $9 \mathrm{~km}$ north-east of Florac, near the village of Les Bondons (Fig. 1). Based on palynology, the first Mesozoic deposits lying unconformably on pre-Hercynian and

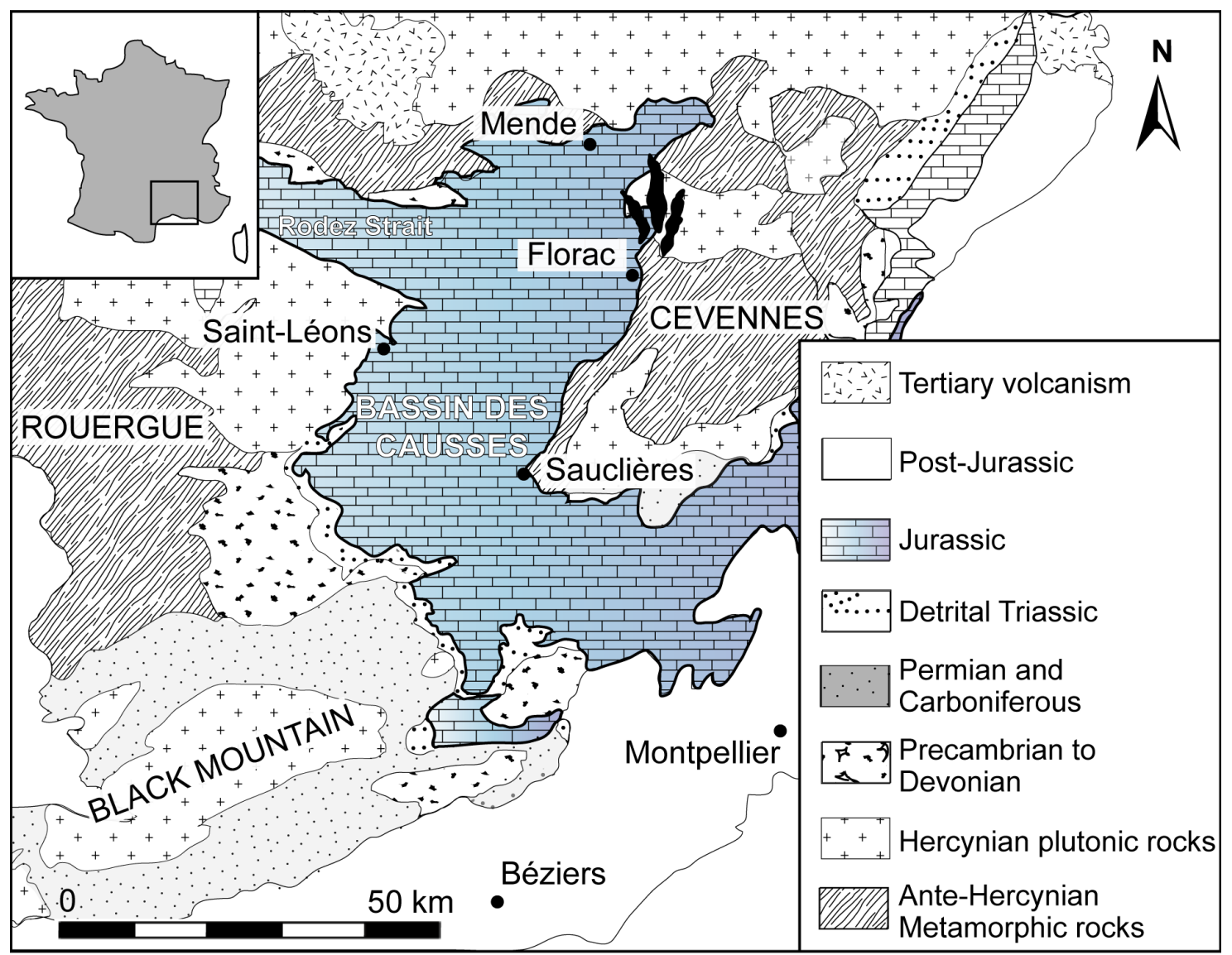

Fig. 1. Location and geological context of the Causses Basin. The black footprint indicates the Malaval Cave. Modified after Grigniac and Taugourdeau-Lantz (1982).
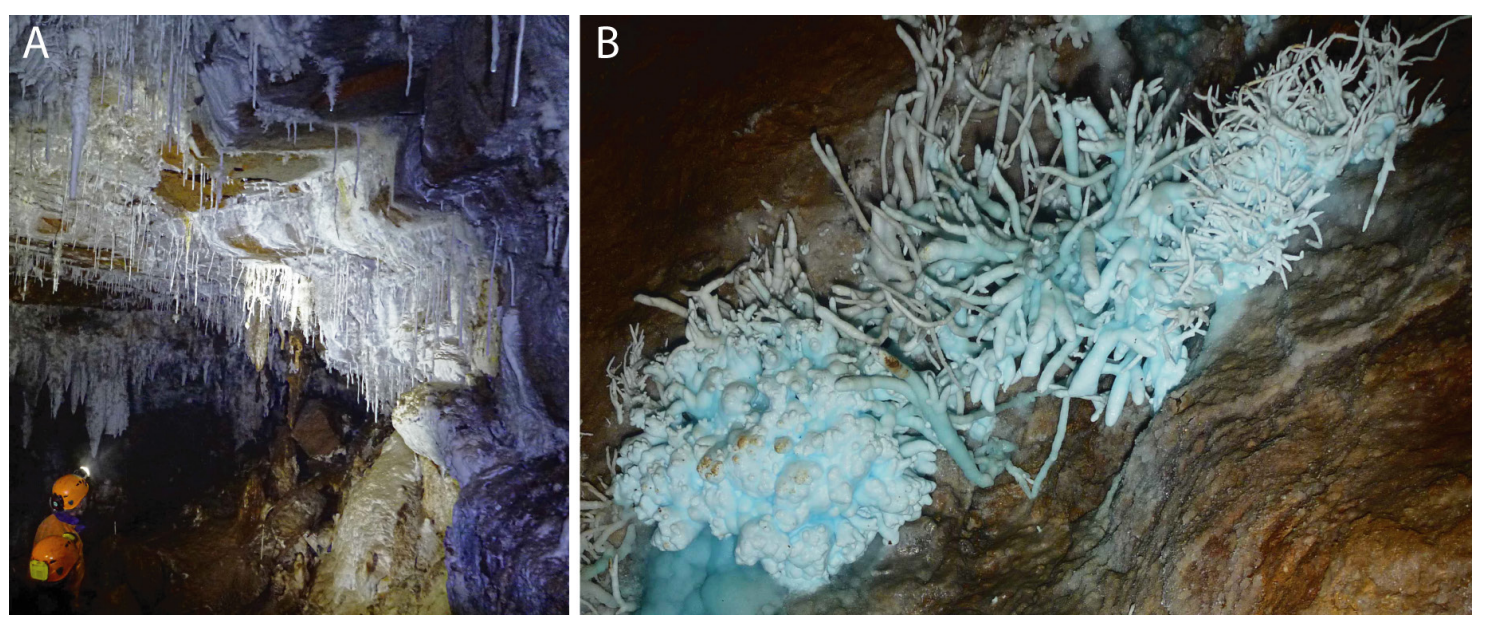

Fig. 2. A) part of the "Super-Blanches" galleries showing abundant white aragonite speleothems; B) characteristic blue helictite aragonite from the Malaval Cave. 
Hercynian crystalline rocks of Lozère are RhetianHettangian or Hettangian in age (Briand etal., 1979, 1993; Grigniac \& Taugourdeau-Lantz, 1982; TaugourdeauLantz, 1983). In Lozère, Hettangian deposits were divided into two informal formations (Brouder et al., 1977; Briand et al., 1979; Gèze et al., 1980): (1) the detrital Sandstones-variegated mudstones Formation and (2) the Dolomitic Formation. The first formation consists of rubefied lenticular and channelized sandstones which alternate with variegated argillites or marls (Simon-Coinçon, 1989). Near Florac, this formation is poorly developed (a few metres thick) or missing (Gèze et al., 1980) and is largely dominated by white or ferruginous sandstones. The second formation consists of both dolomitic limestone and dolomite organized in thin or massive irregular layers alternating with green, blue or black clay beds. They are locally lignitic (Dorlhac, 1860; Gèze et al., 1980). Near Florac, the Dolomitic Formation reaches 80 to 100 metres thick. It corresponds to the beginning of the earliest Jurassic marine transgression and the installation of marginal-littoral palaeoenvironments in the Causses Basin.

The dinosaur tracks described in this study were discovered in the Dolomitic Formation. Except for trackways of vertebrates and some continental plants, fossils are extremely rare in this formation. Indeed, in Lozère, only rare bivalves (e.g., Cardinia concinna, Liostrea sp., Ostrea irregularis) and unidentified gastropods were mentioned (Brouder et al., 1977; Briand et al., 1979; Gèze et al., 1980).

The Malaval Cave contains a karstic network at least $12 \mathrm{~km}$ long (André, 1992). Because of the exceptional abundance of aragonite helictite speleothems, the "Super-Blanches" galleries are probably the most spectacular area of the cavity (Fig. 2). They are up to $300 \mathrm{~m}$ long (Fig. 3A). The tracks described in this study were found in one gallery of the "SuperBlanches" group: the "Galerie des Dalles" (Fig. 3A-B).

Figure 3C shows the stratigraphic section of the "Galerie des Dalles" and the location of the trackbearing beds. This stratigraphic column displays brown to yellow, decimetric, tabular, carbonaceous beds (Units 1, 3, 5, 7, and 8). They alternate with thin, grey and sometime lenticular clayey layers (Units 2, 4 , and 6). Three trace-bearing surfaces were observed in both Unit 1 (Surface A) and Unit 3 (Surfaces B and $\mathrm{C})$. It is interesting to note that Unit 3 bears desiccation cracks (Fig. 3C) and base of Unit 7 displays circular structures firstly observed by Michel Wienin and Jean-Louis Galéra in 2006 and which could be interpreted as synsedimentary deformations such as putative mud volcanoes.

\section{MATERIAL AND METHODS}

The tracksite of the "Super-Blanches" galleries was discovered by Daniel André and Jean-Pierre Malafosse in 2006. They firstly observed two tridactyl tracks on the roof of the cave. In 2013, six other tracks were observed during a speleological trip organized with the Association Paléontologique des Hauts Plateaux du Languedoc (Mende). Then, in 2017, in order to find new tracks, study them and determine the geological context, a field mission was co-organized by members of the Association Malaval (Ispagnac) and those of the A.P.H.P.L.

\section{Petrographic and mineralogical analyses}

Petrographic and mineralogical studies were focused on the main unit yielding footprints: the Unit 3. In addition, in order to compare data with units without tracks, analyses were leaded in Units 6 and 7. Four samples were prepared for both optical microscopy on standard polished thin sections and grinded to perform mineralogical analyses. X-ray fluorescence spectrometry (XRF), X-ray diffraction (XRD), thermogravimetry coupled with mass spectrometry (TGA-MS) and volumetric method (Bernard calcimeter) were conducted at the Génie Civil \& Environnemental laboratory from Douai (IMT Lille-Douai).

$X R F-$ Rock chemistry. Bulk rock analyses were performed using a Bruker S4 Pioneer spectrometer, a $4 \mathrm{~kW}$ wavelength dispersive $\mathrm{X}$-ray fluorescence spectrometer equipped with a rhodium anode. Measurements were performed at $60 \mathrm{keV}$ and $40 \mathrm{~mA}$ on powdered rock compressed tablets. The integrated standardless evaluation of the machine allows the fast and easy determination of element concentrations up to the ppm-level without performing a calibration.

$X R D$-Rock mineralogy. Hand ground powders were analysed using a Bruker D8 Advance diffractometer system using Co-Ka radiation equipped with a fast LynxEye linear detector. The diffractometer was operated at $35 \mathrm{kV}$ and $40 \mathrm{~mA}$. Scans were run from $5^{\circ}$ to $80^{\circ} 2 \theta$, with a step interval of $0.02^{\circ} 2 \theta$ and a goniometry speed of $2 \mathrm{~s}$ per step. The identification of minerals was performed using Bruker-AXS's DiffracPlus EVA software and the ICDD (The International Centre for Diffraction Data) Powder Diffraction File 2015 database. Mineral quantification was made by Rietveld refinement (Rietveld, 1969) with the DIFFRACplus TOPAS software, version 4.2 (Bruker-AXS). The Rietveld method consists in minimizing the difference between an experimental diffractogram and a diffractogram calculated for a given starting model. Crystal structure data were taken from the ICDD PDF and Bruker Structure Database. Rietveld refined parameters used in this study are described in Trincal et al. (2014). Mineral content standard deviations were obtained by the multiplication of the standard deviation given by Topas software by the GOF (goodness of fit) in order to have a faithful approximation (Taylor \& Hinczak, 2003; Trincal et al., 2014).

Carbonate quantification. To confirm the Rietveld data which are often discussed, two independent methods were used to quantify the carbonates in our samples. Bernard calcimetry is a volumetric standardized method (Afnor, NF P94-048) conventionally used on sediments and in civil engineering (e.g., Lamas et al., 2005). Five analyses of pure lime were used for calibration and three analyses were performed for each sample. The precision of the measurements is classically better than 5\% (e.g., Jaquet et al., 1971). The second method was thermogravimetry coupled 

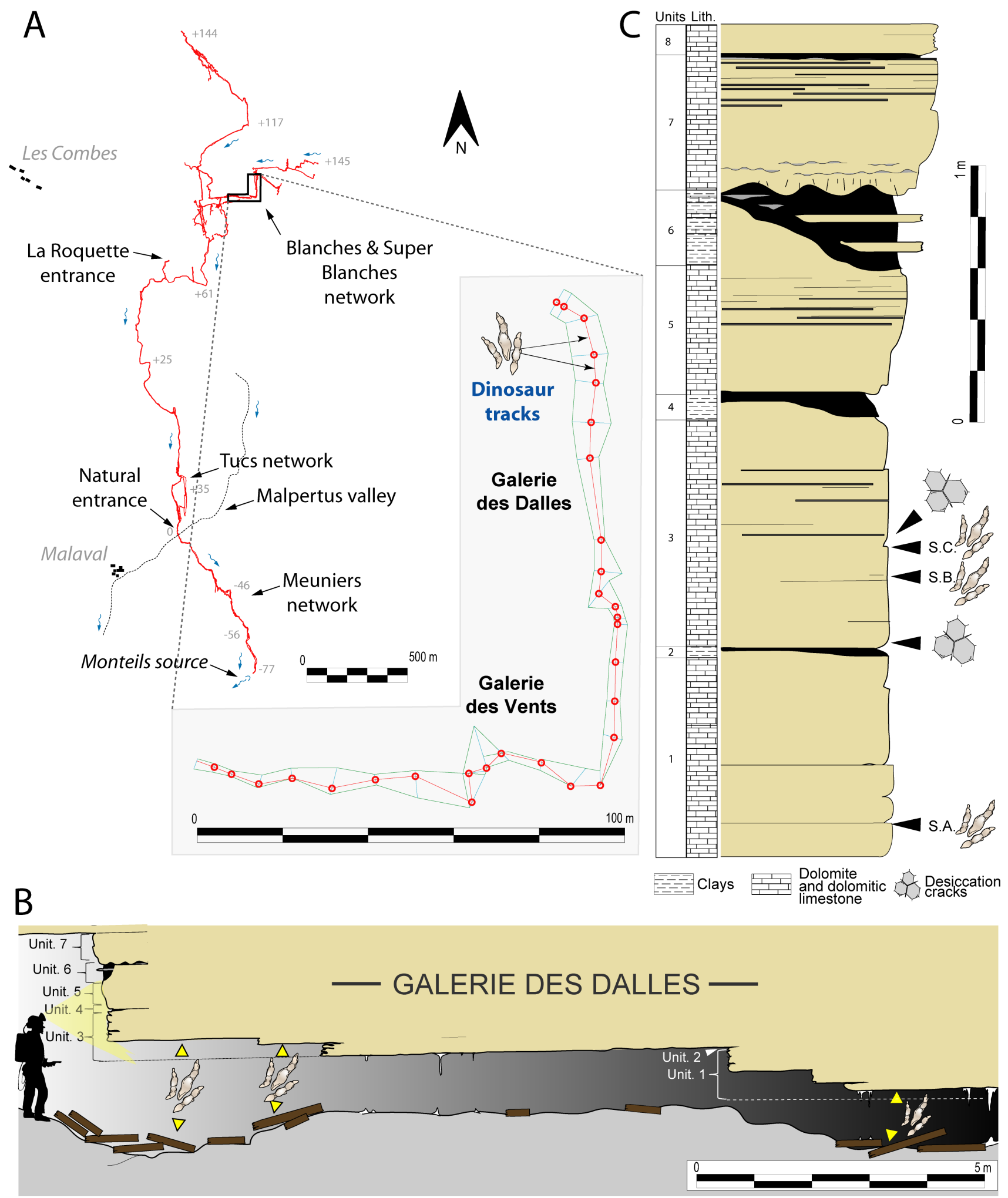

Fig. 3. A) Map of the Malaval Cave and details of the "Super-Blanches" galleries showing location of tracks in the "Galerie des Dalles"; B) sketch of the transversal section of the "Galerie des Dalles" and location of tracks; C) stratigraphic section of the "Galerie des Dalles". S.A., Surface A; S.B., Surface B; S.C., Surface C; Li., lithology.

with mass spectrometry (TGA-MS) (e.g., Kulp et al., 1951). Analyses were conducted using a Netzsch STA 449 F3 Jupiter thermal analyser coupled with a Netzsch QMS 403 D Aëlos quadrupole mass spectrometer. This configuration allows measurement of gas and mass changes of a powdered sample under the effect of temperature. Setup was configured for a temperature increase of $3^{\circ} \mathrm{C} /$ minute from 40 to $1000^{\circ} \mathrm{C}$ under an argon stream. Sample mass variation measurement was quantitative during analyses, while gas estimation was qualitative.

\section{Trace fossil analysis}

The material consists of tridactyl footprints, comprising traces of digits II, III and IV, directly measured on the accessible roof of the cave and fallen isolated blocks (Figs. 4-7). The descriptive terminology and biometric parameters used here are inspired from Leonardi (1987) and Marty (2008). We used the following standard abbreviations: length of the trace, "L"; width of the trace, "W"; lengths of the digits, "LII", "LIII", "LIV"; divarication angle between digit II and digit IV, "II-IV" (Fig. 4). We also used "D" 
which corresponds to the length of the free part of digit III sensu Demathieu et al. (2002). This is not to be confused with D for Depth. None of the specimens, included those from isolated blocks were collected.

In order to produce an orthoimage of the largest track-bearing surface (Fig. 5A), we used Agisoft PhotoScan Professional to align and combine multi digital photographs (Panasonic Lumix DMC-FT1). The same software was used to produce photogrammetric 3D textured meshes. The 3D renderings were created using the MeshLab 1.3.2 software (Fig. 5B). Because of no ideal conditions (reduce field of view due to low ceilings), photogrammetry was very useful to have a better representation of the entire track-bearing surfaces and to reveal traces undetected during the first field investigations. Data of the 3D models are available online on the open access database of https://figshare.com.

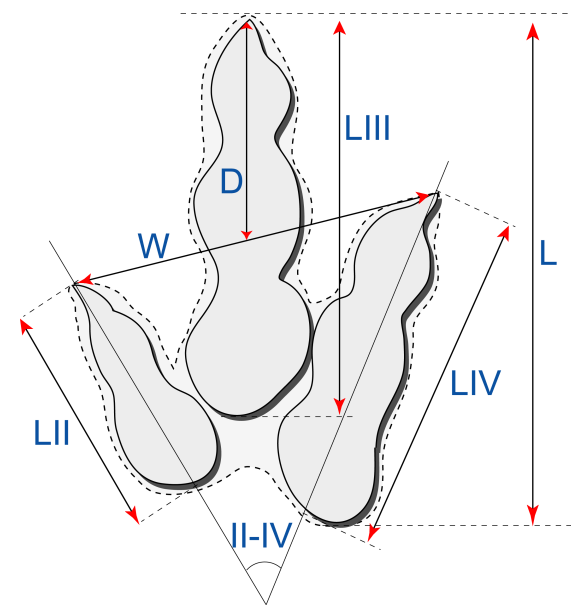

Fig. 4. Schematic tridactyl track showing the biometric parameters measured; length of the trace, L; width of the trace, W; digits lengths, LII, LIII, LIV; lengths of the free part III, D; divarication angle between II and IV, II-IV.
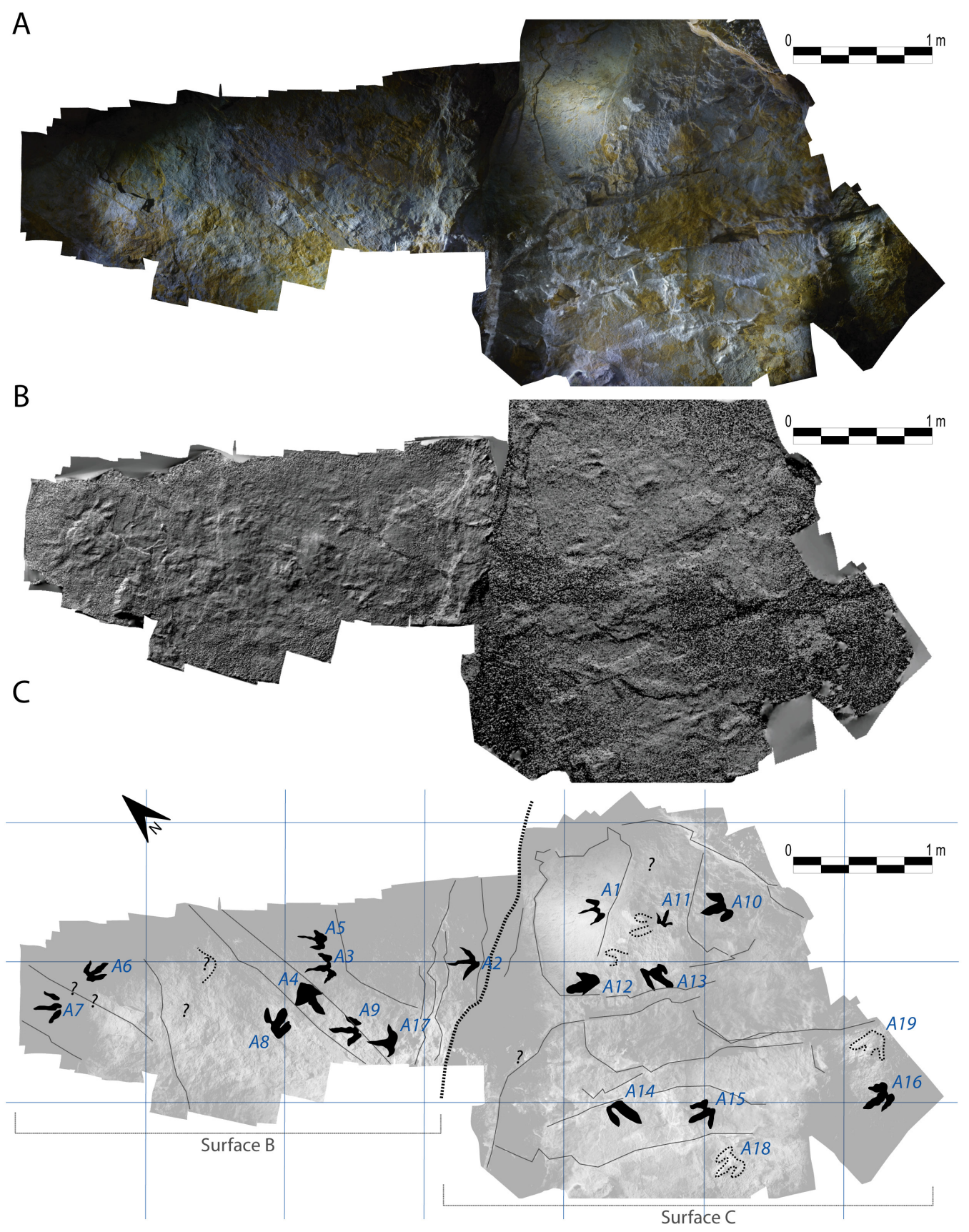

Fig. 5. Main track-assemblage of the "Galerie des Dalles" including "Surfaces B" and "Surface C".

A) model combining multi digital photographs of the ceiling of the cave; B) 3D rendering of the same model; C) interpretative sketch. 

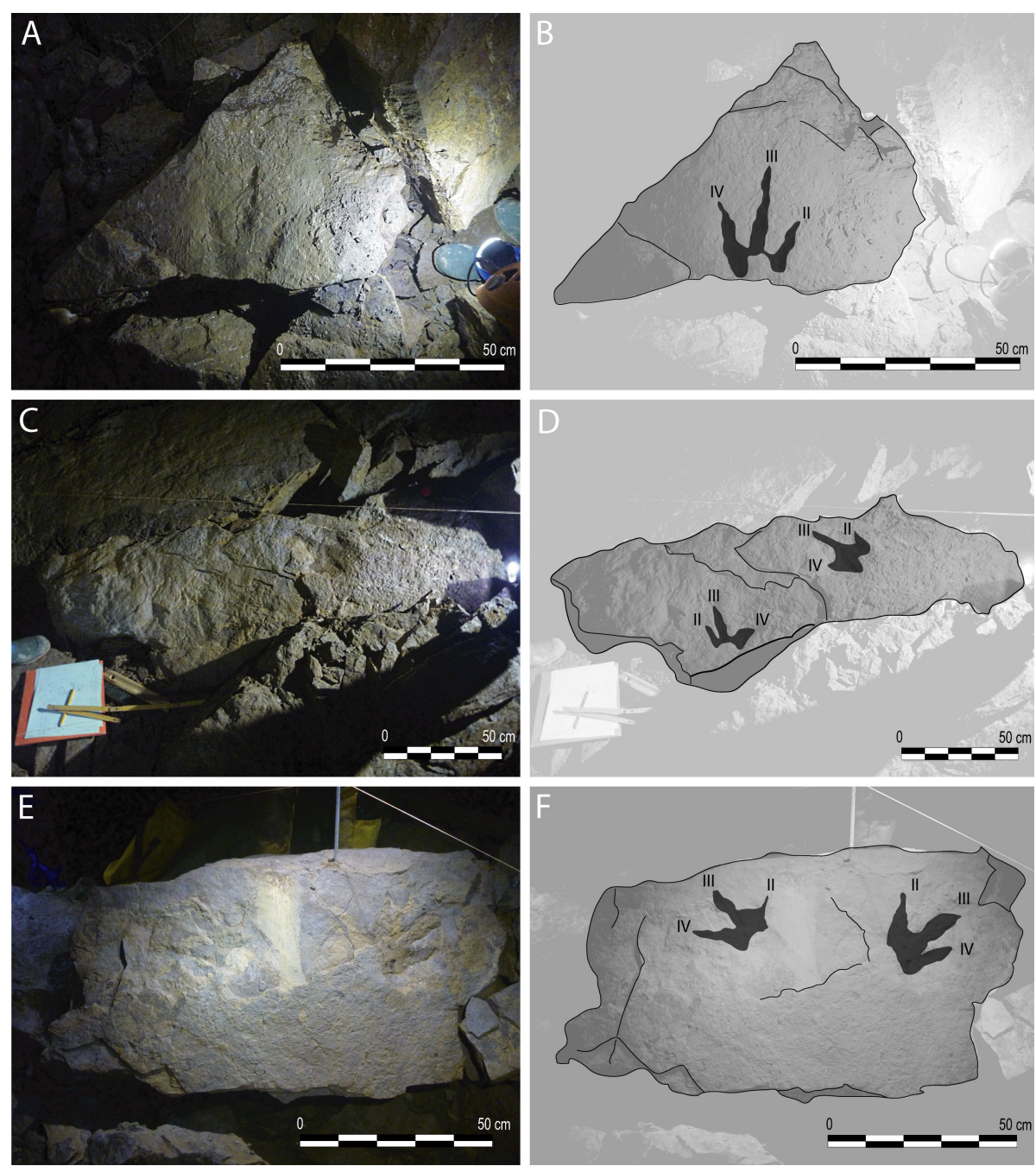

Fig. 6. Isolated blocks bearing tracks from the "Galerie des Dalles". A-B, A16"; C-D, D1 and D2; $\mathrm{E}-\mathrm{F}, \mathrm{B} 1$ and B2.
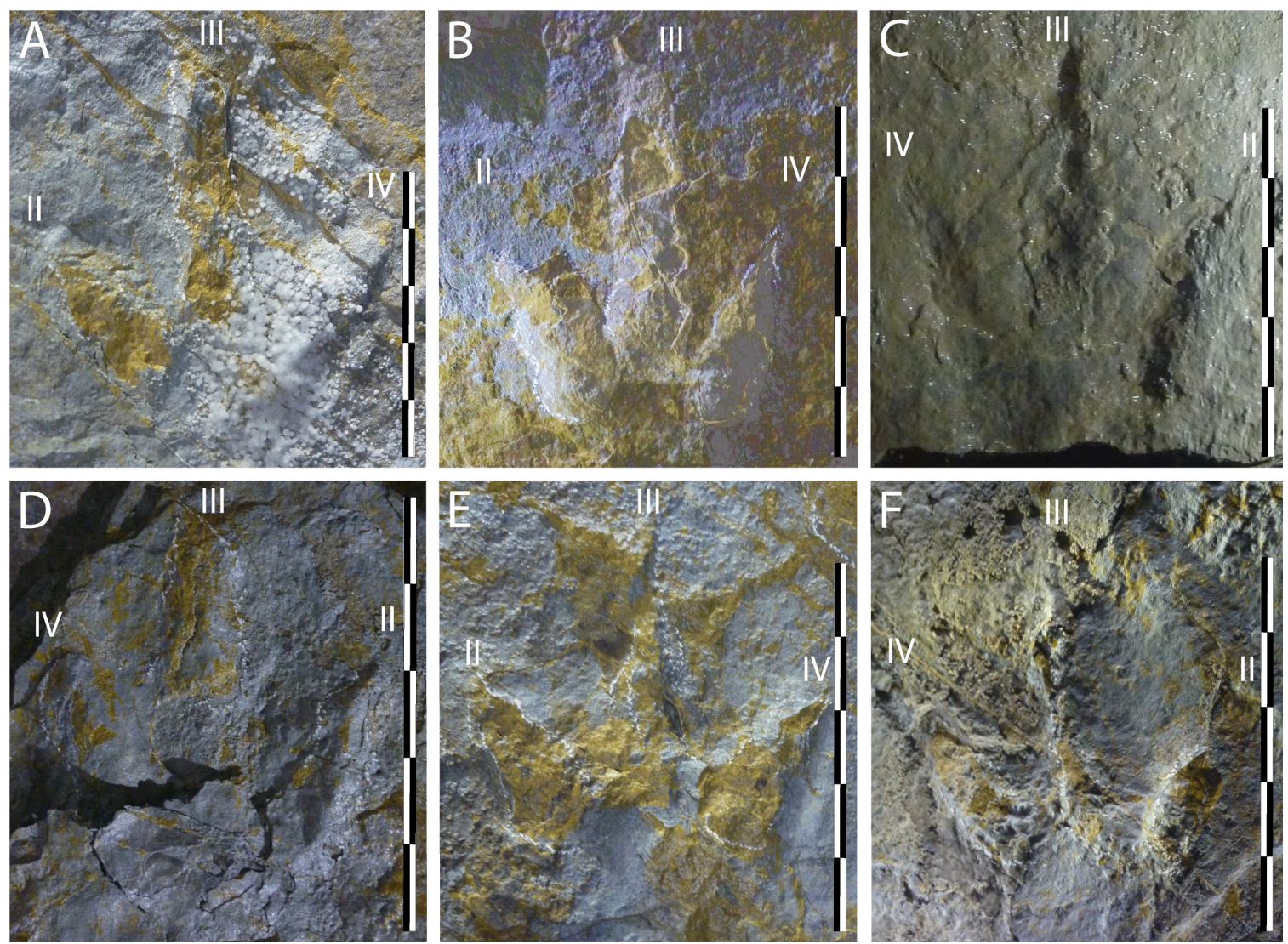

Fig. 7. Illustration of some dinosaur traces from the Hettangian tracksite of the Malaval Cave. A) A9; B) A16; C) A16'; D) A15; E) A3; F) A7. Concave epirelief, C. Convex hyporeliefs, A, B, D, E, F. All scale bars, $25 \mathrm{~cm}$. 


\section{RESULTS}

\section{Petrography and mineralogy}

Petrographic observations of Unit 3 revealed that dinosaur tracks are preserved in dolomudstone with millimetre-thick cryptalgal laminites microfacies (Fig. $8 \mathrm{~A}$ and $\mathrm{C}$ ). The microbial laminae are parallel to the bedding planes and wavy to planar. The cryptalgal laminites exhibit non-porous fabric and a mudstone texture with rare detrital particles and an absence of bioclasts. Unit 7 is a bioturbated dolomudstone highly perturbed (Fig. 8B and D).

XRD Rietveld quantifications (Table 1A) indicate that dolomite is the main component of the surfaces bearing traces (Unit 3). According to analysed samples, they are composed by 81 to $87 \mathrm{wt} \%$ of dolomite, 5 to $8 \mathrm{wt} \%$ of calcite, 3 to $6 \mathrm{wt} \%$ of quartz and less than 6 wt $\%$ of clays (illite and kaolinite; Fig. 9 and Table 1). Except the calcite decrease compensated by a dolomite increase, the mineralogy of Unit 7 is close to those of Unit 3. Due to the difficulty to well used Rietveld refinement method on sedimentary rocks (e.g., Trincal et al., 2014), carbonaceous quantifications (dolomite plus calcite) were confirmed using both Bernard calcimetry and TGA-MS independent methods on Units 3, 6, and 7 (Table 1B). Clayey rock from Unit 6 shows according to Rietveld refinement method, $51 \mathrm{wt} \%$ of illitic clays, 25wt\% of dolomite and $16 \mathrm{wt} \%$ of quartz while calcite and kaolinite are both less than $4 \%$ t (Table 1A). However, the large $10 \AA$ XRD peak (Fig. 9) suggests a mix between two illitic populations or a randomly mixed-layer phase. The first assumption was used for Rietveld refinement. Carbonaceous analyse with independent methods supports the Rietveld quantification on this Unit 6 argilaceous rock (Table 1B), results which are coherent with XRF data (Supplemental File 1).

Organic matter was identified by XRF in all samples, but not quantified (Supplemental File 1). However, the pyrolysis of the organic matter generates a peak of $\mathrm{CO}_{2}$ between 100 and $500^{\circ} \mathrm{C}$ (e.g., Pietro \& Paola, 2004). TGA-MS spectrums performed on Malaval cave samples indicate a small loss of mass in this temperatures range, without $\mathrm{CO}_{2}$ release (Supplemental File 2). This loss of mass probably corresponds to clay dehydration. TGA-MS results suggest very low organic matter content in these rocks, probably less than $1 \mathrm{wt} \%$.
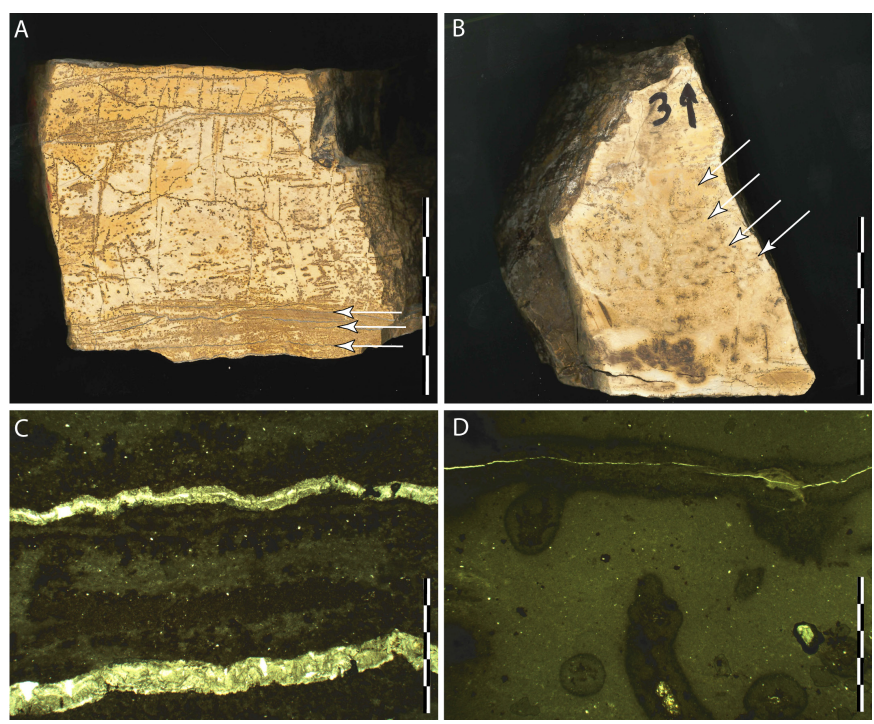

Fig. 8. A-D, main dolomitic facies. A and C (Unit 3), dolomudstone with cryptalgal laminites (arrows), gross morphology (A) and microfacies (C). B and D (Unit 7), bioturbated dolomudstone, gross morphology (B) and microfacies (D); arrows indicate bioturbations. Scale bars, A-B, $5 \mathrm{~cm}$; C-D, $2 \mathrm{~mm}$.

\section{The track-bearing surfaces}

Twenty in situ convex hyporeliefs are distributed over the ceiling of the "Galerie des Dalles". According to the preservation scale proposed by Belvedere \& Farlow (2006), which includes four grades from 0 to 3, footprints from Malaval show preservation grades 0 to 2 . One track is preserved on "Surface A" whereas nineteen tracks are preserved as the assemblage composed of "Surface B" and "Surface C" (Fig. 5C). In addition, three putative footprints were distinguished on "Surface A" but these are not convincing. Six ex situ tracks preserved as concave epireliefs were discovered onto three isolated blocks found on the floor of the cave (Fig. 6). Although the "Super-Blanches" galleries are characterized by the abundance of aragonite speleothems, they are absent in the parts of the gallery yielding footprints. Because of karstic weathering, preservation of the tracks from the "Surface B" and "Surface C" are not of consistent quality. Best preserved impressions show well distinguished pads and claws (Fig. 10). Some traces appear to be undertracks rather than "true tracks". Most of the footprints are oriented toward the northwest. Among the complete traces, three morphotypes can be distinguished (Fig. 10; Table 2).

"Grallatorid" morphotype. The first morphotype is represented by 3 isolated ichnites. Tracks are small

Table 1. A) Proportions of minerals given in Malaval samples by Topas software Rietveld refinement from XRD analyses. GOF: goodness of fit in percent. Rwp: weighted residual percent. The variances given in this table correspond to the standard deviation given by Topas software multiplied by the GOF. B) Carbonates (calcite and dolomite) estimations obtained by Rietveld refinement (a), Bernard calcimetry (b) and TGA-MS (c).

\begin{tabular}{|c|c|c|c|c|c|c|c|c|}
\hline \multirow{4}{*}{ A } & Sample & Dolomite & Calcite & Quartz & Kaolinite & Illite & GOF & Rwp \\
\cline { 2 - 9 } & Unit 7 & $91.2 \pm 0.8$ & $0.7 \pm 0.9$ & $2.84 \pm 0.3$ & $1.23 \pm 0.5$ & $2.9 \pm 1.1$ & 1.73 & 7.81 \\
\cline { 2 - 10 } & Unit 6 & $24.9 \pm 0.4$ & $3.7 \pm 0.4$ & $16 \pm 0.2$ & $3.52 \pm 0.9$ & $51.5 \pm 1.6$ & 1.87 & 7.86 \\
\cline { 2 - 10 } & Unit 3, S.C. & $86.28 \pm 0.9$ & $5.75 \pm 0.4$ & $4.37 \pm 1.5$ & $1.59 \pm 0.4$ & $1.71 \pm 0.8$ & 1.58 & 7 \\
\cline { 2 - 10 } & Unit 3, S.B. & $81.17 \pm 0.9$ & $7.67 \pm 0.4$ & $5.89 \pm 0.2$ & $1.82 \pm 0.4$ & $3.2 \pm 0.9$ & 1.58 & 7.24 \\
\hline
\end{tabular}

\begin{tabular}{|c|c|c|c|c|}
\hline \multirow{4}{*}{ B } & Sample & a & b & c \\
\cline { 2 - 5 } & Unit 7 & 92 & 89 & 85 to 92 \\
\cline { 2 - 5 } & Unit 6 & 29 & 29 & 31 to 33 \\
\cline { 2 - 5 } & Unit 3, S.C. & 92 & 91 & 85 to 92 \\
\cline { 2 - 5 } & Unit 3, S.B. & 89 & 89 & 83 to 90 \\
\hline
\end{tabular}




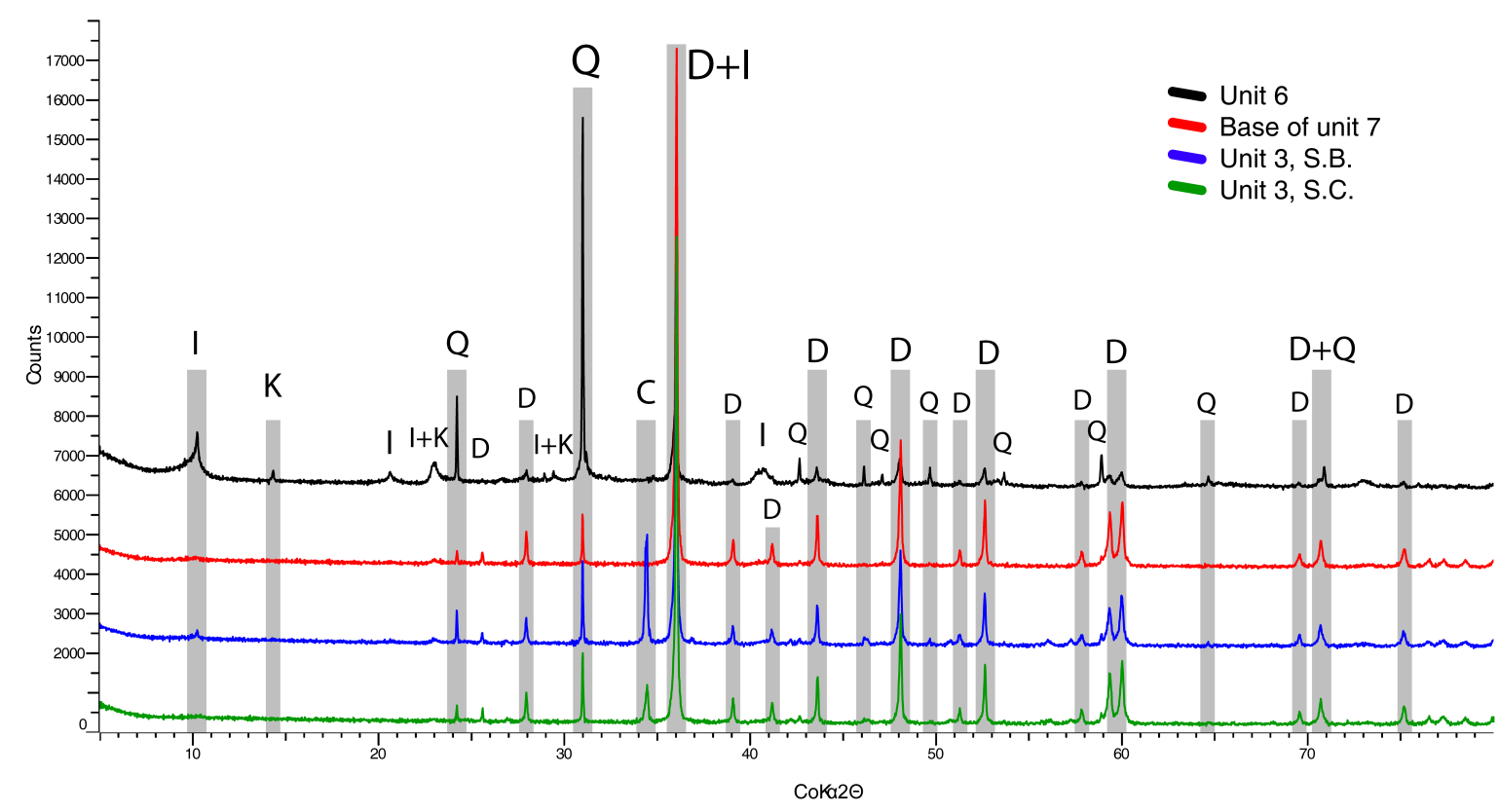

Fig. 9. X-ray diffractograms obtained on bulk rock samples. From the bottom to top: Unit 3, S.C.; Unit 3, S.B.; Base of unit 7; and Unit 6. Key: C: calcite; D: dolomite; I: illite; K: kaolinite; Q: quartz.

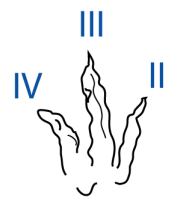

A11

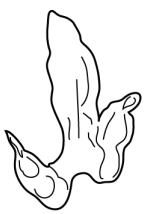

A13

"Grallatorid" morphotype

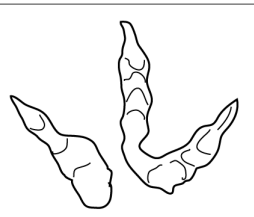

A2

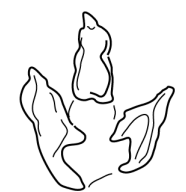

A6

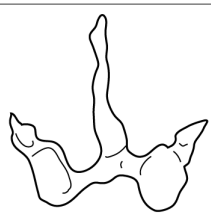

A3

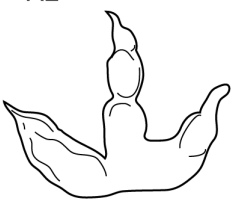

A7

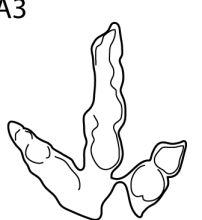

A9

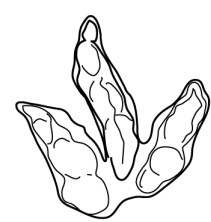

A15

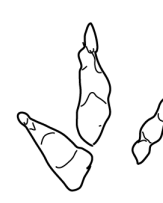

C1

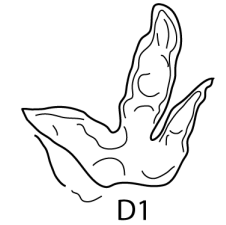

"Dilophosauripus-Kayentapus" morphotype

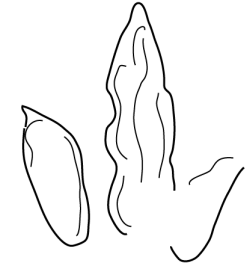

A14

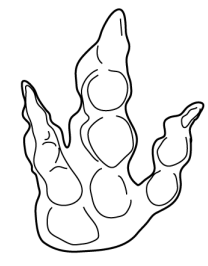

A16
"Eubrontes" morphotype

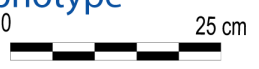

Fig. 10. Sketch of the three morphotypes from the Malaval Cave. "Grallatorid" morphotype A11 and A13. "Dilophosauripus-Kayentapus" morphotype, A2, A3, A6, A7, A9, A15, C1, and D1. "Eubrontes" morphotype, A14 and A16. Digits II, III, and IV from right to left. to medium-sized, longer than wide $(\mathrm{L} / \mathrm{W}=1.1-1.6)$, 14-29 $\mathrm{cm}$ long and $12.5-20.0 \mathrm{~cm}$ wide. The angle between II and IV is 39-44. Impressions of digits are well-defined, elongated and they sometime show claw marks. The trace of digit III is the longest. The length of the free part of digit III is quite long (L/D = 2.0-2.6). Impressions of digital pads are well preserved and are circular to oval. The position of the digito-metatarsal pad of digit IV is more proximal than of digit II. There is no plantar impression.

"Dilophosauripus-Kayentapus" morphotype. The second morphotype consists of 12 isolated footprints and represent the most abundant traces in the ichnological assemblage from Malaval. One partial trackway composed of two consecutive tridactyl IIIV tracks (A2-A3; Fig. 5C) displays a $109 \mathrm{~cm}$ pace length. Tracks are as long as wide or larger than long $(\mathrm{L} / \mathrm{W}=0.8-1.1), 16-29 \mathrm{~cm}$ long and 18-26 cm wide. The divarication angle between II and IV is large, $65^{\circ}$ in average (II-IV $=43-85^{\circ}$ ). Impressions of digits are moderately elongated. Those of digit III is longer than those of digits II and IV. Length of II and IV are quite close. Imprints of pads are often weakly marked whereas traces of claws are well-visible.

"Eubrontes" morphotype. The third morphotype consists of 2 isolated and larger ichnites. Tracks are longer than wide (L/W = 1.3), 29-30 cm long and up to $23 \mathrm{~cm}$ wide. The divarication angle between II and IV is quite large (II-IV $=47^{\circ}$ ) and D is short. The position of the digito-metatarsal pad of digit IV is more proximal than digit II. The best preserved footprint displays large impressions of digits and wellmarked pads.

\section{DISCUSSION}

\section{Comparison with other Early Jurassic tracks and probable trackmakers}

In European dinosaur tracksites, Grallator is an ichnogenus commonly reported from the Hettangian deposits of Italy (e.g., Avanzini et al., 2006), France 
Table 2. Values measured on Hettangian tridactyl tracks from the "Super-Blanches" galleries in the Malaval Cave. "L", length of the trace; "W', width of the trace; "LII", "LIII", "LIV" lengths of the digits; "II-IV" divarication angle between digit II and digit IV; "D", length of the free part of digit III (all in cm except II-IV in degrees). Morphotype 1, "Grallatorid" morphotype; Morphotype 2, "Dilophosauripus-Kayentapus" morphotype; Morphotype 3 "Eubrontes" morphotype.

\begin{tabular}{|c|c|c|c|c|c|c|c|c|}
\hline Track number & L & W & LII & LII & LIV & D & II-IV & Morphotype \\
\hline A1 & 21 & 21 & 9.5 & 17 & 12 & 8 & 60 & Morphotype 2 \\
\hline A2 & 24 & 25 & 10 & 20 & 13 & 12 & 85 & Morphotype 2 \\
\hline A3 & 23 & 22.5 & 11 & 18.5 & 11.5 & 12 & 65 & Morphotype 2 \\
\hline A4 & 29 & 20 & - & - & - & 11 & 39 & Morphotype 1 \\
\hline A5 & 23 & 15 & 10 & 17 & 11 & 11 & 35 & - \\
\hline A6 & 18 & 18 & 8 & 11 & 11 & 8 & 43 & Morphotype 2 \\
\hline A7 & 21 & 26 & 8 & 16 & 14 & 9.5 & 68 & Morphotype 2 \\
\hline A8 & & - & - & - & - & - & - & - \\
\hline A9 & 24 & 21 & 10 & 18 & 12 & 12.5 & 62 & Morphotype 2 \\
\hline A10 & 26 & 25 & - & 23 & 13 & 14 & 46 & Morphotype 2 \\
\hline A11 & 14 & 12.5 & 7 & 10 & 7 & 6 & 42 & Morphotype 1 \\
\hline A12 & 26 & - & - & - & - & - & 60 & - \\
\hline A13 & 25 & 16 & 9 & 18 & 13 & 12 & 44 & Morphotype 1 \\
\hline A14 & 30 & - & - & - & - & - & - & Morphotype 3? \\
\hline A15 & 23 & 26 & 14 & 18 & 18 & 9 & 53 & Morphotype 2 \\
\hline A16 & 29 & 23 & 19 & 20 & 20 & 11 & 47 & Morphotype 3 \\
\hline B1 & 22 & 17 & 10 & 18 & 16 & 9 & 46 & - \\
\hline B2 & 21 & 23 & - & - & - & 9 & 80 & Morphotype 2 \\
\hline C1 & 16 & 20 & 9.5 & 13 & 11 & 7 & 78 & Morphotype 2 \\
\hline C2 & 24 & 18 & 18 & 19 & 11 & 11 & 38 & - \\
\hline D1 & 29 & - & 10 & - & 12 & 10 & 70 & Morphotype 2 \\
\hline D2 & 24 & - & - & - & - & 12 & 78 & Morphotype 2 \\
\hline
\end{tabular}

(e.g., Demathieu et al., 2002; Gand et al., 2007; Moreau et al., 2012a, 2014), Poland (e.g., Gierliński et al., 2004; Niedźwiedzki \& Pieńkowski, 2016) and Sweden (e.g., Ahlberg \& Siverson, 1991; Lockley \& Meyer, 2000). In the Causses Basin, four ichnospecies of Grallator were previously reported Grallator lescurei (Demathieu, 1990), G. minusculus (Hitchcock, 1858), G. sauclierensis (Demathieu \& Sciau, 1992), and G. variabilis (de Lapparent \& Montenat, 1967). Among "Grallatorid" morphotype from the Malaval Cave, one isolated track (A11; Fig. 10) shares some similarities with both $G$. variabilis and $G$. sauclierensis. $G$. variabilis was described based on material from the tidal flat area of Le Veillon (Vendée, western France; de Lapparent \& Montenat, 1967) and G. sauclierensis was described based on material from the Sauclières quarry (Aveyron, southern France; Demathieu \& Sciau, 1992): small track (i.e., $14 \mathrm{~cm}$ long) longer than wide, well distinguished and thin traces of digits, digito-metatarsal pad of digit IV more proximal than of digit II. Although they are abundant in the middle and southern part of the Causses Basin (Demathieu et al., 2002), small Grallator traces seem less common in northern part of the basin (Moreau et al., 2014). Two footprints from the Malaval Cave (A4 and A13; Fig. 10) present some similarities with the largest Grallator ichnospecies, G. lescurei and G. minusculus, described based on material from the Saint-Léons quarry (Aveyron, southern France, Demathieu, 1990), and the Harford and Deerfiled Basins (Connecticut and Massachusetts; Hitchcock, 1858), respectively: up to $30 \mathrm{~cm}$ long and longer than wide track, large impressions of digits, moderate divarication angle II-IV and pads well distinguished. It is noteworthy that Demathieu (2003) reported strong similarities between G. minusculus from the Causses and $G$. maximus (de Lapparent \& Montenat, 1967) described based on material from Vendée. Except the Causses Basin and the Vendée, Grallator was also reported from other French tracksites dispersed in Dordogne (Gand et al., 2007), Hérault (Bogdanoff et al., 1984; Gand et al., 2007) and Var (Ellenberger, 1965).

Although the validity of the ichnotaxon Dilophosauripus (Welles, 1971) is debatable according to some authors (see Lucas et al., 2006), this ichnogenus was reported from Hettangian-Sinemurian deposits of numerous localities in France (e.g., Demathieu \& Sciau, 1992; Demathieu, 1993; Demathieu et al., 2002; Sciau, 2003; Demathieu \& Gand, 2003; Gand et al., 2007). "Dilophosauripus-Kayentapus" morphotype from Malaval shares many similarities with Dilophosauripus williamsi described by Demathieu et al. (2002) from the Hettangian-Sinemurian deposits of the Causses Basin: medium-size footprint (i.e., $22 \mathrm{~cm}$ in average), values of the ratio $\mathrm{L} / \mathrm{W}$ close to 1 , large divarication angle between II and IV, and impressions of II and IV quite similar in length. However, D. williamsi described by Demathieu et al. (2002) shows smaller values of divarication angle II-IV (i.e., $54^{\circ}$ in average) than the "Dilophosauripus-Kayentapus" morphotype from the Malaval Cave. Sciau (2003) and Moreau et al. (2012a, 2012b, 2014) mentioned up to $98^{\circ}$ values in Dilophosauripus from Aveyron and Lozère. It demonstrates the broad variability of the divarication angle II-IV, probably depending of the nature and the hydration of substratum. In France, with the exception of the Causses Basin, few tracks from the Hettangian of Dordogne were ascribed to Dilophosauripus (Gand 
et al., 2007). Otherwise, it is interesting to note that some authors consider Dilophosauripus as a junior synonym of Eubrontes and Kayentapus (Welles, 1971) to be the valid ichnotaxon (see references in Lucas et al., 2006; Lockley et al., 2011). In the Lower Jurassic deposits from Europe, although Kayentapus was not previously reported from France, this ichnogenus was reported from Hungary (Gierliński, 1996), Italy (Avanzini et al., 2006) and Poland (Gierliński \& Niedźwiedzki, 2005).

Among European dinosaur tracksites, Eubrontes is an ichnogenus which was reported from the Hettangian deposits of Italy (e.g., Avanzini et al., 2006), France (e.g., Demathieu et al., 2002 and references therein; Moreau et al., 2012a, 2014) and Poland (e.g., Gierliński et al., 2004). In the Hettangian deposits of France, Eubrontes (total length longer than $25 \mathrm{~cm}$ sensu Olsen et al., 1998) is represented by E. giganteus (Hitchcock, 1845) and E. veillonensis (de Lapparent \& Montenat, 1967), described based on material from Connecticut, USA (Lull, 1953) and Vendée, respectively. Both ichnospecies seem to show many morphological similarities. However, E. veillonensis (total length, $34 \mathrm{~cm}$ in average) is smaller than E. giganteus (Gand et al., 2007). Although "Eubrontes" morphotype from Malaval share some similarities with E. giganteus described from the Hettangian of the Causses Basin (e.g., large digit impressions; value of $\mathrm{L} / \mathrm{W}=1.24$ in average; short free part of digit III), they are smaller (i.e., up to $51 \mathrm{~cm}$ in length among E. giganteus from Aveyron; Demathieu \& Sciau, 1999). We may notice that smallsized Eubrontes (i.e., 27-33 cm long) were reported in the northern part of the Causses Basin and the Rodez Strait (Moreau et al., 2012a, 2014). Although they can show similar length, E. giganteus differs with $G$. minusculus by a larger divarication angle (i.e., higher than to $40^{\circ}$ ) and a smaller L/W value (i.e., 1.24 and 1.58 in E. giganteus and G. minusculus respectively; Demathieu et al., 2002). Except the Causses Basin and the Vendée, Eubrontes was also reported from other French tracksites dispersed in areas such as Dordogne (Gand et al., 2007), Lot (Lange-Badré \& Lafon, 2000) and Var (Ellenberger, 1965).

The phalangeal formula inferred for the trackmakers of Grallator and Eubrontes (3, 4 and 5 pads for toes traces II, III and IV) allow these ichnogenera to be linked to theropod dinosaurs (Demathieu et al., 2002). However, because tracks with high value of divarication angle and $\mathrm{L} / \mathrm{W}$ ratio close to 1 are often linked with ornithopods, the likely trackmaker of Dilophosauripus is debatable. Based on values of (L-D)/D lower than 2.75, Demathieu et al. (2002) demonstrated that Dilophosauripus is more probably related to theropods. Dilophosauripus differs from ornithopod footprints by the presence of sharp claw impressions (Thulborn, 1990). Worldwide, bone remains of Early Jurassic theropods were ascribed to Coelophysidea and Ceratosausoria (i.e., Weishampel et al., 2004 and references therein; Smith et al., 2007; Xing et al., 2013). In Europe, their body fossils are known from the Hettangian deposits of England, France and Luxembourg (Larsonneur \& Lapparent,
1966; Carrano \& Sampson, 2004; Delsate \& Ezcurra, 2014). However, in France, they remain extremely rare. Unknown from the Hettangian of the Causses Basin, French Hettangian theropods bones are only represented by Lophostropheus airelensis from the Moon-Airel Formation at Normandie (northwestern France; Larsonneur \& Lapparent, 1966; Cuny \& Galton, 1993; Ezcurra \& Cuny, 2007).

\section{Palaeoenvironmental reconstruction}

Near Florac, the rare bivalves and gastropods, as well as the rare ammonites (e.g., Psiloceras planorbis) reported in the Hettangian Dolomitic Formation attest of local marine inputs (Brun \& Marcelin, 1934; Brouder et al., 1977; Briand et al., 1979; Gèze et al., 1980). However, in the same formation, near Mende, lignite beds yielding plant remains indicate the presence of local conifer-dominated forest (Thévenard, 1993). The most abundant remains are cuticles ascribed to leafy axes and cones of conifers (e.g., Pagiophyllum peregrinum, Brachyphyllum paparelii; Thévenard, 1993), more rarely to leaves of Ginkgoales (c. Eretmophyllum caussenense Thévenard, 1992). The co-occurrence of marine and terrestrial fossils in the Dolomitic Formation attests to marginal-littoral environments.

In the "Super-Blanches" galleries, the cryptalgal laminites are characteristic of the intertidal and supratidal zones of a tidal flat showing microbial mats (e.g., Alsharhan \& Kendall, 2003; Hamon, 2004; Matysik, 2016). The lack of bioclasts and coarse sediment suggest limited storm-generated transport. All the elements may reflect a relative distance between the track-bearing surfaces and the subtidal zones. The non-porous fabric of the cryptalgal laminites shows that the depositional environment was regularly flooded. However, the desiccation cracks and the dinosaur imprints indicate that sediments were deposited in an environment which was emergent periodically. Otherwise, the bioturbated dolomudstone observed in the beds without tracks suggest shallow subtidal zone, deposited in protected area of strong tidal currents (e.g., Hamon, 2004; Matysik, 2016). Therefore both dolomudstones facies suggest that depositional environments varied from sub-tidal to intertidal/supratidal areas in a large and flat marsh. This hypothesis is also supported by evidence of putative mud volcanoes which are common in tidal environments (i.e., Eisma, 1998). The absence of invertebrate skeletal fossils suggest restricted life conditions, probably related to increase salinity, but still suitable for pervasive bioturbation (Matysik, 2016). At Mende, $15 \mathrm{~km}$ NNW of the Malaval Cave, the Dolomitic Formation yielded halite pseudomorphs, suggesting local evaporitic conditions (Moreau, 2011).

Two categories of dolomite are commonly distinguished: primary dolomite precipitating directly from aqueous solution mostly at or near to $20-35^{\circ} \mathrm{C}$ without $\mathrm{CaCO}_{3}$ dissolution; and secondary dolomite replacing the mineral calcite (Banerjee, 2016 and references therein). In the Causses Basin, the Hettangian dolomite was tentatively interpreted as both primary dolomite (at least partly; Alabouvette 
et al., 1988; Gauthier \& Disnar, 1984; Defaut et al., 1990) and early diagenetic dolomite, suggesting multiorigins (Hamon, 2004). The palaeoenvironmental hypothesis of a tidal flat marsh can be supported by the following arguments: penecontemporary dolomite is identified in current environments such as shallow lagoons, subtidal and evaporitic intertidal to supratidal mud flats with strong microbial mat influence (e.g., sabkhas; Skinner, 1963; Illing et al., 1965; Shinn et al., 1965; Irion \& Müller, 1968; Bontognali et al., 2010); laboratory experiments demonstrated that microbial activity facilitate and increase the formation of dolomite (Bontognali et al., 2010, 2014; Banerjee, 2016 and references therein); and dolomite is formed where tidal flooding and storm sediments are followed by many days of subaerial exposure (Shinn et al., 1965).

In present and fossil tidal flats, clayey component commonly displays illite-dominated assemblage coupled with other diverse clay minerals such as smectite, kaolinite, and chlorite (e.g., Suttill et al., 1982; Marty, 2008). For example, in the Late Jurassic from Switzerland (Marty, 2008), laminites intervals yielding dinosaur footprints are characterized by illite-dominated clay assemblage (55-70\%) followed by illite/smectite mixed-layers (30-45\%) and locally by some kaolinite. Although kaolinite as well as smectite can be illitised during diagenesis (Lanson et al., 2009; Chamley, 2013) it is interesting to notice that low kaolinite/illite ratio (e.g., Unit 6) might indicate that immature palaeosols can be a source for the clay minerals (Marty, 2008). Provenance of clays cannot be unequivocally established and remains debatable. However, it is noteworthy that Hamon \& Merzeraud (2008) reported illite-dominated pedogenic horizons in peritidal facies from the Dolomitic Formation of the south of the Causses Basin.

\section{CONCLUSION}

The combination of speleological prospecting and photogrammetric investigation allow twenty six tracks to be discovered and documented. They are mainly preserved as in situ convex hyporeliefs onto the ceiling of the "Galerie des Dalles". The Hettangian fossil traces from the Malaval Cave are all tridactyl footprints ascribed to three morphotypes, "Dilophosauripus Kayentapus" morphotype, "Eubrontes" morphotype and "Grallatorid" morphotype, which are related to theropods. Dinosaur tracks are preserved in dolomudstone with millimetre-thick cryptalgal laminites microfacies. Palaeontology, sedimentology and mineralogy indicate that the depositional environment varied from subtidal to intertidal/ supratidal flat marsh which was emergent periodically. This new tracksite definitively highlights the great interest and importance of palaeoichnological investigation in karst caves.

\section{ACKNOWLEDGEMENTS}

We thank the Association Malaval for the access to the cavity. We thank Matteo Belvedere and Martin Lockley for their constructive reviews on the manuscript. Authors also thank Johanna Caboche, Damien Betrancourt and Guillaume Potier, from the GCE department (Douai), for their contribution to mineralogical analyses. This publication is a contribution to a project led by the A.P.H.P.L. (Mende, Lozère).

\section{REFERENCES}

AFNOR, 2003 - NF P 94-048: Reconnaissance et essais - Détermination de la teneur en calcite - Méthode du calcimètre.

Ahlberg A. \& Siverson M., 1991 - Lower Jurassic dinosaur footprints in Helsingborg, southern Sweden. Geologiska Föreningens i Stockholm Förhandlingar, 113: 339-340. https://doi.org/10.1080/11035899109453209

Alabouvette B., Arrondeau J.-P., Aubague M., Bodeur Y., Dubois P., Mattei J., Paloc H. \& Rancon J.-P., 1988 Notice explicative, carte géologique au 1/50.000ème de la France, feuille Le Caylar (962). Bureau de Recherches Géologiques et Minières, Orléans, 63 p.

Alsharhan A.S. \& Kendall C.S.C., 2003 - Holocene coastal carbonates and evaporites of the southern Arabian Gulf and their ancient analogues. Earth-Science Reviews, 61: 191-243.

https://doi.org/10.1016/S0012-8252(02)00110-1

André D., 1992 - Lozère des ténèbres. Spéléo Club de la Lozère, Saint-Georges-de-Luzençon, 257 p.

André D., 2014 - Le docteur Jean Gajac (1913-1973): inventeur de la célèbre grotte Malaval. Bulletin de la Société des Lettres Sciences et Arts de la Lozère, 37: 11-26.

Avanzini M., Piubelli D., Mietto P., Rogho G., Romano R. \& Masetti D., 2006 - Lower Jurassic (HettangianSinemurian) dinosaur track megasites, southern Alps, Northern Italy. In: Harris J.D., Lucas S.G., Spielmann J.A., Lockley M.G., Milner A.R.C. \& Kirkland J.I. (Eds.), The Triassic-Jurassic terrestrial transition. New Mexico Museum of Natural History and Science Bulletin, 37: 207-216.

Banerjee A., 2016 - Estimation of dolomite formation: Dolomite precipitation and dolomitization. Journal of the Geological Society of India, 87: 561-572. https://doi.org/10.1007/s12594-016-0430-9

Belvedere M. \& Farlow J., 2006 - Introduction a numerical scale to quantify the preservation grade of vertebrate tracks. In: Falkingham P., Marty D. \& Richter A. (Eds.), Dinosaur tracks - Next steps. Indiana University Press, Bloomington, p. 92-99.

Belvedere M., Mietto P., Avanzini M. \& Rigo M., 2008 - Norian dinosaur footprints from the "Strada delle Gallerie" (Monte Pasubio, NE Italy). Studi Tridentini Scienze Naturali, Acta Geologica, 83: 267-275.

Bogdanoff S., Donnot M. \& Ellenberger F., 1984 - Notice explicative à de la feuille à 1/80.000 de Bédarieux. Bureau de Recherches Géologiques et Minières, Orléans, $105 \mathrm{p}$.

Bontognali T.R., Vasconcelos C., Warthmann R.J., Bernasconi S.M., Dupraz C., Strohmenger C.J. \& McKenzie J.A., 2010 - Dolomite formation within microbial mats in the coastal sabkha of Abu Dhabi (United Arab Emirates). Sedimentology, 57: 824-844. https://doi.org/10.1111/j.1365-3091.2009.01121.x

Bontognali T.R.R., McKenzie J.A., Warthmann R.J. \& Vasconcelos C., 2014 - Microbially influenced formation of $\mathrm{Mg}$-calcite and $\mathrm{Ca}$-dolomite in the presence of exopolymeric substances produced by sulphatereducing bacteria. Terra Nova, 26: 72-77. https://doi.org/10.1111/ter.12072 
Briand B.-G., Couturié J.-P., Geffroy J. \& Gèze B., 1979 Notice explicative, carte géologique au 1/50.000ème de la France, feuille de Mende (862). Bureau de Recherches Géologiques et Minières, Orléans, 52 p.

Briand B.-G., Combémorel R., Couturié J.-P., Bérard P. \& Vaurelle C., 1993 - Notice explicative, carte géologique au 1/50.000ème de la France, feuille du Bleymard (863). Bureau de Recherches Géologiques et Minières, Orléans, $76 \mathrm{p}$.

Brouder P., Gèze B., Macquar J.C. \& Paloc H., 1977 Notice explicative, carte géologique au 1/50.000ème de la France, feuille de Meyrueis (910). Bureau de Recherches Géologiques et Minières, Orléans, 29 p.

Brun de P. \& Marcelin P., 1934 - Étude stratigraphique des petits causses des environs de Florac (Lozère). Bulletin de la Société d'Histoire Naturelle de Toulouse, 66: 377-391.

Carrano M.T. \& Sampson S.D., 2004 - A review of coelophysoids (Dinosauria: Theropoda) from the Early Jurassic of Europe, with comments on the late history of the Coelophysoidea. Neues Jahrbuch für Geologie und Paläontologie-Monatshefte, 9: 537-558.

Chamley H. 2013 - Clay sedimentology. Springer, New York, 656 p.

Cook A.G., Saini N. \& Hocknull S.A., 2010 - Dinosaur footprints from the Lower Jurassic of Mount Morgan, Queensland. Memoirs of the Queensland Museum (Nature), 55: 135-146.

Cuny G. \& Galton P.M., 1993 - Revision of the Airel theropod dinosaur from the Triassic-Jurassic boundary (Normandy, France). Neues Jahrbuch für Geologie und Paläontologie, Abhandlungen, 187: 261-288.

Defaut B., Burg J.P.B., Astruc J.G., Leyreloup A.F., Romney F., Fuchs Y., Alabouvette B., LefavraisRaymond A., Roux J., Senaud G., Paloc H. \& Vautrelle C., 1990 - Notice explicative de la carte géologique à 1/50 000 de Sévérac-le-Château (885). Bureau de Recherches Géologiques et Minières, Orléans, 58 p.

Delsate D. \& Ezcurra M.D., 2014 - The first Early Jurassic (late Hettangian) theropod dinosaur remains from the Grand Duchy of Luxembourg. Geologica Belgica, 17: $175-181$.

Demathieu G., 1990 - Problem in discrimination of tridactyl dinosaur footprints, exemplified by the Hettangian trackways, the Causses, France. Ichnos, 1: 97-110.

https://doi.org/10.1080/10420949009386339

Demathieu G., 1993 - Empreintes de pas de dinosaures dans les Causses (France). Zubía, 5: 229-252.

Demathieu G., 2003 - Comparaison des ichnopopulations des Grands Causses (Sud de la France) et du Veillon (Vendée). Le Naturaliste Vendéen, 3: 59-60.

Demathieu G. \& Gand G., 2003 - Les sites à traces de pas de vertébrés du Trias à Hettangien. Le Naturaliste Vendéen, 3: 47-53.

Demathieu G. \& Sciau J., 1992 - Des pistes de Dinosaures et de Crocodiliens dans les dolomies de l'Hettangien du Causse du Larzac. Comptes Rendus de l'Académie des Sciences de Paris, 315: 1561-1566.

Demathieu G. \& Sciau J., 1999 - De grandes empreintes de pas de dinosaures dans l'Hettangien de Peyre (Aveyron, France). Geobios, 32: 609-616. https://doi.org/10.1016/S0016-6995(99)80010-2

Demathieu G., Gand G., Sciau J. \& Freytet P., 2002 - Les traces de pas de dinosaures et autres archosaures du Lias inférieur des Grands Causses, Sud de la France. Palaeovertebrata, 31: 1-143.

https://doi.org/10.18563/pv.31.1-4.1-143
Dorlhac A.M., 1860 - Esquisse géologique du département de la Lozère. Bulletin de la Société d'Agriculture, Industrie, Sciences et Arts du Département de la Lozère, 11: 374-479.

Eisma D., 1998 - Intertidal deposits: river mouths, tidal flats, and coastal lagoons. CRC Press, Boca Raton, Florida, $459 \mathrm{p}$.

Ellenberger P., 1965 - Découverte de pistes de vertébrés dans le Permien, le Trias et le Lias inferieur aux abords de Toulon (Var) et d'Anduze (Gard). Comptes Rendus de l'Académie des Sciences de Paris, 260: 5856-5860.

Ellenberger P., 1988 - La découverte des pistes de dinosauriens de Camprieu. Causses et Cévennes, 7: 139-140.

Ezcurra M.D. \& Cuny G. 2007 - The coelophysoid Lophostropheus airelensis, gen. nov.: a review of the systematics of "Liliensternus" airelensis from the Triassic-Jurassic outcrops of Normandy (France). Journal of Vertebrate Paleontology, 27: 73-86. https://doi.org/10.1671/0272-4634(2007)27 [73:TCLAGN]2.0.CO;2

Gajac J., 1963 - La rivière souterraine de Malaval. Cévennes et Mont-Lozère, 1: 5-6.

Gajac J. \& Rouire J., 1949 - Le plateau des Bondons et la grotte Malaval. Annales de Spéléologie, 4: 125-132.

Gand G., Demathieu C. \& Montenat, C., 2007 - Les traces de pas d'amphibiens, de Dinosaures et autres Reptiles du Mésozoïque français: inventaire et interprétations. Palaeovertebrata, 35: 1-149.

https://doi.org/10.18563/pv.35.1-4.1-149

Gauthier B., \& Disnar J.-R., 1984 - Etude de la matière organique des séries carbonatées minéralisées: le Lias du gite $\mathrm{Zn}-\mathrm{Pb}$ de Trèves. Bureau de Recherches Géologiques et Minières, Orléans, 46 p.

Gèze B., Pellet J., Paloc H., Bambier A., Roux J. \& Senaud G., 1980 - Notice explicative, carte géologique au 1/50.000ème de la France, feuille de Florac (886). Bureau de Recherches Géologiques et Minières, Orléans, $52 \mathrm{p}$.

Gierliński G., 1996 - Dinosaur ichnotaxa from the Lower Jurassic of Hungary. Geological Quarterly, 40: 119-128.

Gierliński G. \& Ahlberg A., 1994 - Late Triassic and Early Jurassic dinosaur footprints in the Höganäs Formation of southern Sweden. Ichnos: An International Journal of Plant \& Animal, 3 (2): 99-105.

https://doi.org/10.1080/10420949409386377

Gierliński G. \& Niedźwiedzki G., 2005 - New saurischian dinosaur footprints from the Lower Jurassic of Poland. Geological Quarterly, 49: 99-104.

Gierliński G., Pieńkowski G. \& Niedźwiedzki G., 2004 - Tetrapod track assemblage in the Hettangian of Sołtyków, Poland, and its paleoenvironmental background. Ichnos, 11: 195-213. https://doi.org/10.1080/10420940490444861

Grigniac C. \& Taugourdeau-Lantz J., 1982 - Découverte de microflores d'âge Hettangien dans l'épandage gréso-conglomératique "triasique "formant la base du Mésozoïque de la région de Figeac-Capdenac (Quercy). Comptes Rendus de l'Académie des Sciences de Paris, 295: 57-62.

Hamon Y., 2004 - Morphologie, évolution latérale et signification géodynamique des discontinuités sédimentaires : exemple de la marge Ouest du Bassin du Sud-Est (France). Unpublished PhD thesis, University of Montpellier II, $293 \mathrm{p}$.

Hamon Y. \& Merzeraud G., 2008 - Facies architecture and cyclicity in a mosaic carbonate platform: effects of fault-block tectonics (Lower Lias, Causses platform, south-east France). Sedimentology, 55 (1): 155-178. https://doi.org/10.1111/j.1365-3091.2007.00896.x 
Hitchcock E., 1845 - An attempt to name, classify, and describe the animals that made the fossil footmarks of New England. Proceedings of the $6^{\text {th }}$ Meeting American Association of Geologists and Naturalists. New Haven, Connecticut, p. 23-25.

Hitchcock E., 1858 - Ichnology of New England. A report on the sandstone of the Connecticut Valley, especially its fossil footmarks. William White editions, Boston, 220 p.

Illing L.V., Wells A.J. \& Taylor J.C.M., 1965 Penecontemporaneous dolomite in the Persian Gulf. In: Pray L.C. \& Murray R.C. (Eds.), Dolomitization and limestone diagenesis. The Society of Economic Paleontologists and Mineralogists, 13: 89-111.

Irion G. \& Müller G., 1968 - Huntite, dolomite, magnesite and polyhalite of recent age from Tuz Golü, Turkey. Nature, 220: 1309-1310. https://doi.org/10.1038/2201309b0 Jaquet J.-M., Vernet J.-P. \& Ferrari J.-M., 1971 Détermination quantitative par volumétrie de la calcite et de la dolomite dans les roches. Archives des Sciences, 24: 259-284.

Kralik M., Pavuza R. \& Melikadze G., 2014 Hydrogeological and speleometeorological dynamics of the Prometheus and Sataplia show-caves, Imereti, Georgia. Journal of the Georgian Geophysical Society, 17: 76-101.

Kulp L.J., Kent P. \& Kerr P.F., 1951 - Thermal study of the $\mathrm{Ca}-\mathrm{Mg}-\mathrm{Fe}$ carbonate minerals. American Mineralogist 36: 643-670.

Lamas F., Irigaray C., Oteo C. \& Chacón J., 2005 Selection of the most appropriate method to determine the carbonate content for engineering purposes with particular regard to marls. Engineering Geology, 81: 32-41. https://doi.org/10.1016/j.enggeo.2005.07.005

Lange-Badré B. \& Lafon J.-P., 2000 - Découverte de pistes de dinosaures théropodes dans le Lias inférieur des environs de Figeac (Lot). Comptes Rendus de l'Académie des Sciences de Paris, 330: 379-384. https://doi.org/10.1016/S1251-8050(00)00160-9

Lanson B., Sakharov B.A., Claret F. \& Drits V.A., 2009 - Diagenetic smectite-to-illite transition in clay-rich sediments: A reappraisal of $X$-ray diffraction results using the multi-specimen method. American Journal of Science, 309: 476-516.

https://doi.org/10.2475/06.2009.03

Lapparent A.F. (de) \& Montenat C., 1967 - Les empreintes de pas de reptiles de l'Infralias du Veillon (Vendée). Mémoire de la Société Géologique de France, 46: 43 p.

Larsonneur C. \& Lapparent A.F. (de), 1966 - Un dinosaurien carnivore, Halticosaurus, dans le Réthien d'Airel (Manche). Bulletin Société Linnéenne de Normandie, 10: 108-116.

Leonardi G., 1987 - Glossary and manual of tetrapod footprint palaeoichnology. Publicacão do Departemento Nacional da Produção Mineral Brasil, Brasília, 75 p.

Lockley M.G. \& Hunt A.P., 1995 - Dinosaur tracks: And other fossil footprints of the western United States. Columbia University Press, New York, 338 p.

Lockley M. \& Meyer C., 2000 - Dinosaur tracks and other fossils footprints of Europe. Columbia University Pres, New York, 327 p.

Lockley M.G., Gierliński G. \& Lucas S.G., 2011 Kayentapus revised: notes on the type material and the importance of this theropod footprint ichnogenus. New Mexico Museum of Natural History and Science, 53: 330-336.

Lucas S.G., Lockley M.G., Hunt A.P., Milner A.R. \& Tanner L.H., 2006 - Tetrapod footprint biostratigraphy of the Triassic-Jurassic transition in the American southwest. The Triassic-Jurassic Terrestrial Transition New Mexico of Natural History and Science Bulletin, 37: 105-108.
Lull R.S., 1953 - Triassic life of Connecticut Valley. State geological and Natural History Survey, Hartford, 24, 331 p.

Marty D., 2008 - Sedimentology, taphonomy, and ichnology of Late Jurassic dinosaur tracks from the Jura carbonate platform (Chevenez-Combe Ronde tracksite, NW Switzerland): insights into the tidal-flat palaeoenvironment and dinosaur diversity, locomotion, and palaeoecology. Geofocus, 21: 1-278.

Matysik M., 2016 - Facies types and depositional environments of a morphologically diverse carbonate platform: a case study from the Muschelkalk (Middle Triassic) of Upper Silesia, southern Poland. Annales Societatis Geologorum Poloniae, 86: 119-164. https://doi.org/10.14241/asgp.2016.013

Monod C., 1935 - Du Musée du Désert au Mont-Aigoual, à l'Aven Armand et aux Gorges du Tarn par la Corniche des Cévennes. Causses et Cévennes, Revue du Club Cévenol, 7: 273-280.

Moreau J.-D., 2011 - Nouvelles découvertes d'empreintes de dinosaures en Lozère. Analyse biométrique des traces et synthèse paléoenvironnementale de l'Hettangien. Association Paléontologique des Hauts Plateaux du Languedoc, Mende, $34 \mathrm{p}$.

Moreau J.-D., Gand G., Fara E. \& Michelin A., 2012a - Biometric and morphometric approaches on Lower Hettangian dinosaur footprints from the Rodez Strait (Aveyron, France). Comptes Rendus Palevol, 11: 231-239. https://doi.org/10.1016/j.crpv.2011.12.003

Moreau J.-D., Baret L., Trincal V. \& André D., 2012b Empreintes dinosauroïdes de l'Hettangien de Gatuzières (Lozère, France). Ichnologie dinosaurienne du Jurassique de Meyrueis. Association Paléontologique des Hauts Plateaux du Languedoc, Mende, 5-11.

Moreau J.-D., Trincal V., Gand G., Néraudeau D., Bessière G. \& Bourel B., 2014 - Two new dinosaur tracksites from the Hettangian Dolomitic Formation of Lozère, Languedoc-Roussillon, France. Annales de Paléontologie, 100: 361-369.

https://doi.org/10.1016/j.annpal.2014.04.001

Niedźwiedzki G. \& Pieńkowski G., 2016 - A dinosaur track assemblage from the Upper Hettangian (Lower Jurassic) marginal-marine deposits of Zapniów, Holy Cross Mountains, Poland. Geological Quarterly, 60: 840-856.

Olsen P.E., Smith J.H. \& Mc Donald N.G., 1998 - Type material of the type species of the classic theropod footprint genera Eubrontes, Anchisauripus and Grallator (Early Jurassic, Hartford and Deerfield basins, Connecticut and Massachusetts, U.S.A). Journal of Vertebrate Paleontology, 18: 586-601.

https://doi.org/10.1080/02724634.1998.10011086

Parker L.R. \& Balsley J.K., 1989 - Coal mines as localities for studying dinosaur trace fossils. In: Gillette D.D. \& Lockley M.G. (Eds.), Dinosaur tracks and traces. Cambridge University Press, Cambridge, 353-359.

Parker L.R. \& Rowley Jr. R.L., 1989 - Dinosaur footprints from a coal mine in East-Central Utah. In: Gillette D.D. \& Lockley M.G. (Eds.), Dinosaur tracks and traces. Cambridge University Press, Cambridge, 361-366.

Peterson W., 1924 - Dinosaur tracks in the roofs of coal mines. Natural History, 24: 388-397.

Petti F.M., Bernardi M., Todesco R. \& Avanzini M., 2011 Dinosaur footprints as ultimate evidence for a terrestrial environment in the Late Sinemurian Trento Carbonate Platform. Palaios, 26: 601-606. https://doi.org/10.2110/palo.2011.p11-003r

Pietro M. \& Paola C., 2004 - Thermal analysis for the evaluation of the organic matter evolution during municipal solid waste aerobic composting process. Thermochimica Acta, 413: 209-214. https://doi.org/10.1016/j.tca.2003.09.026 
Rietveld H.M., 1969 - A profile refinement method for nuclear and magnetic structures. Journal of Applied Crystallography, 2: 65-71. https://doi.org/10.1107/S0021889869006558

Sciau J., 2003 - Dans les pas des dinosaures des Causses. Inventaire des sites à empreintes. Association Paléontologique des Causses, Millau, 107 p.

Shinn E.A., Ginsburg R.N. \& Lloyd R.M., 1965 - Recent supratidal dolomite from Andros Island, Bahamas. In: Pray L.C. \& Murray R.C. (Eds.), Dolomitization and limestone diagenesis. The Society of Economic Paleontologists and Mineralogists, 13: 112-123.

Simon-Coinçon R., 1989 - Le rôle des paléoaltérations et des paléoformes dans les socles : l'exemple du Rouergue (Massif Central Français). ENSMP, Mémoire des Sciences de la Terre, 9: 290 p.

Skinner H.C.W., 1963 - Precipitation of calcian dolomites and magnesian calcites in the southeast of South Australia. American Journal of Science, 261: 449-472. https://doi.org/10.2475/ajs.261.5.449

Smith N.D., Makovicky P.J., Hammer W.R. \& Currie P.J., 2007 - Osteology of Cryolophosaurus ellioti (Dinosauria: Theropoda) from the Early Jurassic of Antarctica and implications for early theropod evolution. Zoological Journal of the Linnean Society, 151: 377-421. https://doi.org/10.1111/j.1096-3642.2007.00325.x

Suttill R.J., Turner P. \& Vaughan D.J., 1982 - The geochemistry of iron in recent tidal-flat sediments of the Wash area, England: A mineralogical, Mössbauer, and magnetic study. Geochimica et Cosmochimica Acta, 46: 205-217. https://doi.org/10.1016/0016-7037(82)90247-2

Taugourdeau-Lantz J., 1983 - Associations palynologiques définies dans le Trias languedocien: interprétations stratigraphiques. Cahiers de Micropaléontologie, 3: 5-20.

Taylor J.C. \& Hinczak I., 2003 - Rietveld made easy: a practical guide to the understanding of the method and successful phase quantifications. Sietronics Pty Ltd., Canberra, $201 \mathrm{p}$.
Thaler L., 1962 - Empreintes de pas de dinosaures dans la dolomie du Lias inférieur des Causses. Comptes Rendus Sommaires de la Société Géologique de France, 7: 190-192.

Thévenard F., 1992. - La paléoflore du Jurassique inférieur $d u$ bassin des Causses (France). Etude systématique, stratigraphique et paléoécologique. Unpublished PhD Thesis, Claude Bernard University, 195 p.

Thévenard F., 1993 - Les coniférales du Jurassique inférieur du gisement de Chaldecoste, bassin des Causses (Lozère, France). Review of Palaeobotany and Palynology, 78: 145-166. https://doi.org/10.1016/0034-6667(93)90020-U

Thulborn T., 1990 - Dinosaur tracks. Chapman and Hall, London, $410 \mathrm{p}$. https://doi.org/10.1007/978-94-009-0409-5

Trincal V., Charpentier D., Buatier M.D., Grobety B., Lacroix B., Labaume P. \& Sizun J.-P., 2014 Quantification of mass transfers and mineralogical transformations in a thrust fault (Monte Perdido thrust unit, southern Pyrenees, Spain). Marine and Petroleum Geology, 55: 160-175. https://doi.org/10.1016/j.marpetgeo.2013.12.016

Weishampel D.B., Dodson P. \& Osmolska H., 2004 - The Dinosauria, second edition. University of California Press, Berkeley, 862 p. https://doi.org/10.1525/california/9780520242098. $\underline{001.0001}$

Welles S.P., 1971 - Dinosaur footprints from the Kayenta Formation of northern Arizona. Plateau, 44: 27-38.

Xing L., Bell P.R., Rothschild B.M., Ran H., Zhang J., Dong Z., Zang W. \& Currie P.J., 2013 - Tooth loss and alveolar remodeling in Sinosaurus triassicus (Dinosauria: Theropoda) from the Lower Jurassic strata of the Lufeng Basin, China. Chinese Science Bulletin, 58 (16): 1931-1935.

https://doi.org/10.1007/s11434-013-5765-7 